\title{
Home Rule, Democracy and the Unmaking of the United Kingdom, 1885-1921
}

Le Home Rule, la démocratie et la déconstruction du Royaume-Uni, 1885-1921

\section{Eugenio Biagini}

\section{(2) OpenEdition}

1 Journals

Electronic version

URL: https://journals.openedition.org/rfcb/3842

DOI: $10.4000 /$ rfcb.3842

ISSN: 2429-4373

Publisher

CRECIB - Centre de recherche et d'études en civilisation britannique

\section{Electronic reference}

Eugenio Biagini, "Home Rule, Democracy and the Unmaking of the United Kingdom, 1885-1921", Revue Française de Civilisation Britannique [Online], XXIV-2 | 2019, Online since 19 June 2019, connection on 21 September 2021. URL: http://journals.openedition.org/rfcb/3842 ; DOI: https://doi.org/10.4000/ rfcb.3842

This text was automatically generated on 21 September 2021.

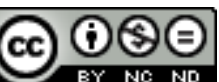

Revue française de civilisation britannique est mis à disposition selon les termes de la licence Creative Commons Attribution - Pas d'Utilisation Commerciale - Pas de Modification 4.0 International. 


\section{Home Rule, Democracy and the Unmaking of the United Kingdom, 1885-1921}

Le Home Rule, la démocratie et la déconstruction du Royaume-Uni, 1885-1921

\section{Eugenio Biagini}

"What fools we were ... not to have accepted Mr
Gladstone's Home Rule Bill. The Empire would not
now have the Irish Free State giving us so much
trouble and pulling us to pieces."
George V in conversation with Prime Minister J. Ramsay

MacDonald, 1930.

\section{Introduction}

From 1885 to 1921 United Kingdom politics were polarized around the question of parliamentary devolution for Ireland (Home Rule). Although the relevant Bills offered only a modest measure of devolution, a major argument against Home Rule was that it would have been incompatible with the survival of the British Empire and indeed of the United Kingdom, because sovereignty could not be divided. However, Home Rule supporters insisted that the proposal was in the Irish national interest. This claim was in itself divisive in Ireland, as well as within the United Kingdom as a whole, and set the South against Ulster, which by 1912 was (literally) up in arms against any idea of weakening or diluting the Union with Britain. By 1887 Liberals in both Scotland and (soon afterwards) in Wales started to campaign for their own form of Home Rule. Indian Liberals were the next to take up the issue, when Dadabhai Naoroji (1825-1917), the Indian Liberal Federation and eventually Congress started to demand Home Rule for the Raj. ${ }^{1}$ Ostensibly only an Irish question, Home Rule was in fact the beginning of a wider debate about the governance of the United Kingdom and the tension between a centralized 
political system and the claims of ethnic groups and distinct regions in a multi-national state - a problem then shared by other multi-ethnic empires in Europe. ${ }^{2}$

This article examines the wider significance of the crisis in the constitutional rebalancing of a liberal, but still undemocratic, state. It will start from the time when the British system was at its apex, between 1707 and 1885. In this period parliament provided social and cultural legitimacy for the centralization of power and created cohesion for the wider imperial project. Second, this article will focus on the advent of democracy from 1885, and the way the latter made it more difficult for parliament to agree on the national interest - especially when the latter depended on finding common ground between four nations.

\section{Halcyon day, 1707-1885}

When England and Scotland merged their parliaments in 1707, neither country was a democracy. The British parliamentary system was one in which men of property exercised real influence not only in electing MPs, but also in the selection of candidates and, most importantly, in identifying those issues about which the government should be concerned. The House of Commons was dominated by large landowners, including the gentry and cadet members of the nobility, some sitting there while waiting their turn to be elevated to the House of Lords upon inheriting the family title. The Upper House represented most of the country's wealth and hereditary confidence in dealing with both national and global affairs.

Parliament played a key role in the forging of a sense of national identity and interest. For several months each year over 600 commoners and a variable number of territorial peers met in the Houses of Parliament to debate matters of common concern; this helped to create a lively awareness of what Benedict Anderson calls the national 'imagined community'. It was an effective way of conjuring up a collective entity which encompassed not only the British Isles, but also the wider Empire, whose affairs became a topic of continuous and informed debate. In this way, Parliament created a sense of the 'national interest'. It was important that they met in London, which was also the country's commercial and financial centre, as well as the hub of imperial communication, where information could be put to good use in terms of choosing investments and shaping policies which would maximize profits. Cohesion among the elite was further consolidated by the development of an integrated education system based on public schools, Oxford and Cambridge. Such cultural centralization helps to understand also why the country could function without a written constitution: the key factor was the cultural and social homogeneity of the ruling elite. The United Kingdom was governed by hereditary experts, organic intellectuals of the landed elite and the upper middle class, confident to be, and be regarded as, essential to the correct operation of a system whose rules were not so much "unwritten", as "hidden amidst a mass of legal precedent and conventions." ${ }^{3}$

5 Though undemocratic, this system was broadly representative. It did not represent citizens and popular majorities, but empowered the people of weight and influence. Even the House of Lords was representative in this sense: each of its members was based in one or more territorial estates, and had personal reasons for looking after the economic interests of those areas where they were located. Furthermore, as a group, they included the great 
shareholders in the Empire project, even in the literal sense of the expression, because of their investments in India, North America and the West Indies. ${ }^{4}$

Their uniquely 'global' perspective on the 'national interest' provided also the rationale behind the development of the so-called 'Court Party' in the eighteenth century. Its supporters were motivated by their involvement in international trade and other global economic interests, which needed to be defended against competitors. They were prepared to fight wars and inflict high taxation on the country for this purpose. They were successful because many other social groups benefited from such a policy, including those associated with the city ports, the ship-building industry, the merchant marine, the navy and its employees, and - last but not least - the slave trade lobby.

7 By contrast, the smaller gentry, whose outlook was based primarily in one specific area, articulated a landed patriotism, which identified the national interest with those of the farming interest. At the time, agriculture was by far the largest employer in the country, and was best served by cheap government and low taxation, which required a small military establishment and the reduction of the national debt - both of which depended on peace abroad. Its advocates, the Country Party, were concerned with the perceived shift of the balance of power from Parliament to the Prime Minister and sought to reassert the power of the landed gentry in contrast to royal officials, large merchants and bankers. ${ }^{5}$

What turned the scales in favour of the Court Party and globalization as the winning definition of the national interest were, first, the great military successes of the eighteenth century, culminating in the securing of new territories in both North America and India after 1760; and, second, the industrial revolution. In turn, empire and industrialization sparked off a long period of expansion of the British economy, including the financial sector, which was the backbone of British power abroad. Great Britain became a focal point for industry and empire, sustaining unprecedented demographic growth at home and what James Belich describes as the settler revolution in colonies overseas, with millions of emigrants creating new countries such as Australia, Canada and New Zealand. ${ }^{67}$

9 The stability of the settler system was ensured by the adoption of devolved representative government for the colonies. Described by Jürgen Osterhammel as the most important constitutional document in nineteenth-century global history, the Durham Report (1839) initiated a process of rapid, albeit selective and racially-exclusive, democratization of the world, starting from the periphery of Europe. ${ }^{8}$ From the 1840 s, there emerged a division of labour between Westminster and colonial governments. The latter were allowed to manage colonial affairs and were responsible to locally elected representative assemblies. This in turn consolidated a two-way flow between foreign and domestic policies: throughout the Victorian age and during the first half of the twentieth century, in exchange for devolution, the Australia, Canada, New Zealand and (later) the 'white' colonies in Africa accepted London's control over their commercial and foreign policy. It was democracy made harmless for the ancien régime, democracy without power.

Yet, in India, the so-called "Mutiny" (or "War of Independence") of 1857-8 demonstrated the limits of paternalism. Ultimately, as Richard Evans has recently reminded us, "violence lay at the heart of the British Empire. ${ }^{9}$ Indeed, this was well known at the time. As the most 'realist' among the system's champions, James Fitzjames Stephen, noted in 1874, in India as much as in Canada or the Scottish Highlands, peace, law and order depended not primarily on consent, but on force, and "the reason why it work[ed] so quietly is that no one doubt[ed] either its existence, or its direction, or its crushing superiority to any individual resistance which could be offered to it." ${ }^{10}$ However, this undemocratic system was restrained 
by a liberal society: domestic public opinion had to be handled with care - which resulted in the early development of a complex relationship between the media and power, as John Wong has demonstrated in his splendid study of the 1856 Opium War. ${ }^{11}$

The weak link in the imperial chain was Ireland. From 1800 its Union with Britain should have provided the country with new opportunities by associating it with the most dynamic economy and the widest territorial and commercial empire on earth. In practice, however, the groups which most benefited from imperial globalisation represented a small cross section of society, while the numerically largest group were the tenant farmers, whose interests were rooted in 'the land' and confined to their villages and counties. The problem was not, as Irish nationalists insisted, that Ireland's 'national interest' diverged from those Britain. Rather - in a variation on the old theme of 'Court versus Country' - in both Ireland and Britain there was a clash between the interests of the farmers and those of the business elite and the urban working classes. These were less important in south-west Ireland than in Britain, but very important both in Ulster and the south-east of Ireland, particularly Dublin. Furthermore, while Belfast had every reason to cherish the Union because its interests coincided with those of industrial Britain, Dublin was divided. Its commercial interests converged with those of England, the largest market for Irish distilleries and confectionary, but the old political elite were resentful of Dublin's loss of status as capital after the Act of Union. ${ }^{12}$ This helps to explain the strange phenomenon of an Irish Protestant 'Tory' patriotism, an attitude best exemplified by Charles Stewart Parnell (1846-91).

The debate on free trade versus agricultural protection was the ideological centrepiece of this clash. During the Napoleonic wars, both British and Irish farmers had benefited from high food prices and steady domestic demand. Through tariffs on imported wheat (the 1815 Corn Laws) the government sought to continue these conditions when peace returned. However, labour unrest and the pressure of the industrial lobby (both of which demanded cheap agricultural imports) forced London to revise the Corn Laws throughout the 1820s and 1830s. Persuaded that free trade was essential to rebalance the economy and avoid revolution, in 1842 the Prime Minister Robert Peel made further steps towards a reduction of agricultural tariffs and in 1846 he pushed through the repeal of the Corn Laws, although this decision split his Conservative party and brought to an end his own political career. While freer trade benefited urban dwellers, it damaged farmers, who did not usually buy their own food, but produced what they needed for family consumption and sold the surplus on the market. Ireland had the largest number of small tenant farmers in the United Kingdom and here the backlash was immediate: the 1842 free trade budget moved hundreds of thousands of poor farmers to coalesce around Daniel O'Connell's campaign for the Repeal of the Union. O'Connell linked the Union with free trade and a restoration of a parliament in Dublin with protection and the farmers' interest. ${ }^{13}$

13 His campaign was abruptly stopped by the greatest economic social and humanitarian catastrophe in the history of the Victorian United Kingdom: the Great Famine (1845-50), which caused the death of about one million people, the immediate exodus of another million and continued emigration over the long term. Survivors, especially those who joined the Irish diaspora in Anglo-phobic, republican America, concluded - not unreasonably - that the United Kingdom did not work for Ireland and that Britain was the main cause of Ireland's woes. ${ }^{14}$ What may be surprising is that this view was not more widely shared by either the Irish who did not emigrate or those in British colonies, such as 
Australia and Canada. One explanation is that a new pattern developed for which Irish and British 'national' interests - and the interest of farmers and city-dwellers converged for at least two generations. The years from 1850 until to 1875 saw a largescale, rapid economic expansion and growth in real wages and living standards sustained by the increase in British demand for Irish corn, beef and butter. Meanwhile, industrial output in Ulster skyrocketed, particularly in shipbuilding, coal and textiles. ${ }^{15}$ However, from the late 1870s improvement in transcontinental and transatlantic communication meant that imported American farm produce started to bring down agricultural prices and erode the Irish share of the United Kingdom market. When this happened, the interests of the rural regions started to diverge again from those of urbanized and industrial areas. While the latter were benefiting from plummeting food prices, Irish farmers felt that their hard-won prosperity was now threatened and demanded a political solution: land redistribution and agricultural protectionism. This helped to reawaken nationalism. In such revival religion was a contributing factor, but hardly a decisive one, for the Catholic hierarchy was predominantly aligned with the British government and committed to the preservation of peace, law and order.

\section{Gemeinschaft and Gesellschaft}

14 The situation in Scotland was comparable, but the outcome was different. Here too there was potential for a revival of Scottish nationalism with significant religious differences, particularly in the aftermath of the 1843 clash between the Presbyterian Church of Scotland (the Kirk) and the state over lay patronage in the appointment of ministers. A majority of the Kirk's supreme governing body - the General Assembly, with both lay and clerical representatives - deliberated that ministers should be elected by congregations, without interference from the local gentry. However, the British Prime Minister (Sir Robert Peel) refused to accept such decision. The General Assembly protested that this was in breach of the 1707 Act of Union. Their argument was rooted in Scottish constitutional and legal thinking - that "the Kirk was an entrenched part of the British constitution, beyond the reach of parliament", because the 1707 Act of Union was "a fundamental law of both realms"; and therefore "no infringement [could] be made upon that [Kirk] establishment without breach of the Union." ${ }^{16}$ In other words, Scotland was understood to have a 'written' constitution, the Act of Union, which, moreover, provided the 'covenanted' foundation of the United Kingdom as a whole. This was a view for which there was much popular support: one minister recalled exclaiming, "on the spur of the moment, that such injustice was enough to justify Scotland in demanding the repeal of the Union. With that, to my surprise, the meeting rose as one man, waving hats and handkerchiefs, and cheering again and again." ${ }^{17}$ In what became known as the Great Disruption, about two fifths of the total membership of the established church seceded to set up a 'Free' Kirk.

While the Disruption did not generate a politically nationalist movement as such, it was " one occasion when hundreds of thousands of ordinary men and women in Scotland challenged the authority set over them. And, unlike other Scottish rebellions, it succeeded, up to a point." ${ }^{18}$ Because it was not based on violence, but on the representative legitimacy of the Kirk's governing body, it attracted broad support - especially in the North, which had least benefited from the Union. The Free Kirk became solidly Liberal (and the Scottish Liberals a surrogate Scottish nationalist party). Within forty-five years of the Disruption Scots started to demand the restoration of their parliament in Edinburgh. ${ }^{19}$ 

main reasons. The first is that at the time Scotland was unquestionably benefiting from both rapid industrialization and urbanization on a scale which was much larger than that experienced by Ireland. While in Ireland industrialization remained confined to the northeast, the industrial belt in Scotland accounted for that country's largest centres of population and wealth and played a major role in steering the national economy. Moreover, Scotland was profiting much more than Ireland from unfettered access to the global markets created by imperial expansion. The latter drove industrial development (shipbuilding, coalmines, textiles) and created overseas employment opportunities (in the army, navy and services, in the education sector and for university graduates, especially medics, law graduates, missionaries and theologians). In 1707 , when the Scottish Act of Union was passed, there were many reasons for Scotland and England to form a Union, including questions of national security and economic interest. In 1800 there were equally good reasons for the Union between Britain and Ireland: again, top of the list was national security against the threat of a French invasion, a prospect which was alarming not only for the British government, but also for the Irish Catholic hierarchy, aware of the policies implemented by the French against the Church and the Pope himself. ${ }^{20}$ It was, however, not a popular decision: in 1800, in order to secure the level of parliamentary support necessary to form a Union, Irish MPs and members of the House of Lords had to be bribed and bullied, while their electors were never consulted. Had they been, it is unlikely that they would have voted for the Union, because ethnic suspicion of the English ran deep and was compounded by religious differences and the fear of Dublin's economic decline. In 1707, the Scottish Union had encountered similar objections and resistance, which had been overcome in similar ways. ${ }^{21}$

There were three major risings between in 1715 and 1798. The Scottish Jacobite rebellions of 1715 and 1745-46 pitched the supporters of the Stuarts (the royal family which had been deposed in 1689) against those of the Hanovers (the Protestant dynasty which had by then produced its first two Georges). The related wars were more brutal and complex than dynastic conflict because they involved a clash between the traditional, kinshipbased system of social obligation of the Highlands, and the market-oriented and globalizing society of Glasgow and Edinburgh. ${ }^{22}$ Popular support for these rebellions had much to do with the Union's failure to integrate the less commercialized, less monetarized parts of Scotland. However, in the end, the economic interests of the large farmers, the city merchants, the shopkeepers and all those involved - directly or indirectly - with the huge and growing overseas trade, demanded the consolidation of the Union. After the Scottish Jacobites were crushed at Culloden (1746), the persistence of tangible external threats, particularly from France (especially from 1756-1816), helped to create a state of patriotic fervor, which consolidated the Union and the insular, 'seaborne' chauvinism.

19 In Ireland, the 1798 United Irishmen's rebellion was more complex, because here the initiative started not from a foreign prince or a group of clan chieftains, but from republican elites strongly represented in large towns and cities, such as Belfast and Dublin. ${ }^{23}$ They were animated by Gesellschaft-oriented ideas of 'universal human rights' and secular democracy. However, after the early stage of the rising, these groups were unable to control peasant insurgency, which again asserted Gemeinschaft values including land hunger and sectarian revenge - against the local representatives of wider, if not global, interests. They were brutally put down by the British army with the help of

Revue Française de Civilisation Britannique, XXIV-2 | 2019 
the local militias, both Catholic and Protestant, staffed by more prosperous farmers and with the blessings of all the churches. ${ }^{24}$

of the two Unions, the Irish one was the less stable for two main reasons. The first is that here the Union had arrived at a time when the Atlantic democratic revolution was well under way (the Irish themselves played a key role in it). ${ }^{25} \mathrm{And}$, the second was because of the way Catholic 'emancipation' (full political rights for Catholics) was achieved in 1829: it was granted by an unwilling government, apparently scared by popular protest - i.e., by democracy. This established a dangerous precedent for the United Kingdom: for, if popular agitation and the threat of violence had 'forced' the government to grant Catholic emancipation, surely more popular unrest would secure anything else the people wanted?

21 The Great Famine killed off domestic revolutionary aspirations for a generation. ${ }^{26}$ As we have seen, after 1850 Ireland was benefiting from the British-led economic boom which continued until the mid-1870s. Towards the end of that decade, however, a series of bad crops, the steady fall in agricultural prices, with most landlords continuing to demand their rents, brought about a new crisis. Under the leadership of a Catholic socialist, Michael Davitt, and a Protestant aristocrat, Parnell, a major new political movement emerged. Parnell's aim was to secure the restoration of a parliament in Dublin, which he regarded as vital to the interest of his own class, the southern Irish gentry, but he presented it as a nationalist demand. Crucially, like Daniel O'Connell in 1842, he linked parliamentary reform to the farmers' interests. ${ }^{27}$ Davitt would have preferred a programme based on co-operative farming, but realized that there was little popular support and great ecclesiastical and middle-class opposition to any form of socialism, and was pragmatic enough to decide that the only way forward was to endorse Parnell's demand for 'tenant right' and Home Rule.

\section{The Advent of 'democracy'}

Much of Parnell's social programme was promptly accepted by the British government. The Prime Minister William E. Gladstone (1809-98) was eager to restore peace, law, order and the legitimacy of the Union. He first targeted the tenant right agitation with radical land reform Acts, the most important of which, in 1881, established what contemporaries called "the Three Fs." These included "fair rents", adjudicated by special courts, rather than defined by market demand and supply mechanisms; "fixity of tenure", in that a farmer could be evicted only for non-payment of the rent; and a tenant's right to "free sale" of the improvements which he had carried out on the farm if he decided to leave it. Land reform was accompanied by a renewal of 'coercion' (anti-terrorist legislation), which became increasingly draconian after Gladstone's nephew, Lord Frederick Cavendish, was murdered by a Fenian group in Dublin's Phoenix Park on the day of his arrival as Ireland's Chief Secretary (6 May 1882). ${ }^{28}$

Such measures were followed by electoral reforms, together amounting to the single most important step towards democracy in a century. The United Kingdom was brought under a uniform electoral system, with (predominantly) single-member constituencies and a first-past-the-post system under household franchise, without property qualifications. It was a sort of 'patriarchal' democracy, under which male heads of households voted, while younger men living at home or in shared accommodation did not. Women were also excluded (though they could vote in some local elections, for example for the powerful 
school boards). In Ireland, the democratic significance of these electoral reforms was increased by the fact that they had been preceded by land reform.

It was supposed to be a new deal for Ireland, one which would make the Union work for the Irish. Instead, it was the beginning of the end of the Union between Britain and Ireland. This was not primarily because Ireland suffered more than England as a result of the decline in agricultural prices, but mainly because, for the first time, 'the people' were consulted about the Union. At the 1885 general election, the Liberals - the party which wanted to make the Union work for the Irish - were squeezed out of Ireland. Most of the southern and western constituencies and about half of the Ulster seats went to Parnell's National party, which demanded Home Rule, while most of north-east Ulster went to the Conservative party, which wanted no further change. ${ }^{29}$

This democratic revolt against the Union was not merely an Irish phenomenon: in the Scottish Highlands a new movement arose, the Crofters' party. Demanding radical land reform on the Irish model, they threatened the Liberal hold over on the north-west. In Wales, the land question mobilized the predominantly Nonconformist tenant farmers against Anglican landlords, while a new Welsh-speaking movement, Cymru Fydd, made inroads into the Liberal party, calling for land reform, Church disestablishment and Home Rule for Wales. ${ }^{30}$

In response to such developments the two main parties adopted radically divergent policies. Gladstone was keenly aware of the power of national separatism and believed that it was important to find a strategy to harness it to the chariot of the Union state. He thought that this could best be done through devolution and land reform. For Scotland, he quickly established the Scottish office, as a new central government department, and implemented a Highlands Land Act similar to the 1881 Irish Land Act to appease the Scottish small farmers (crofters) had started an agitation in $1885 .{ }^{31}$ Wales, where Gladstone had his own country house, would have to wait, but Ireland was the most urgent dimension of the Union problem, because of the political clout secured by Parnell, whose party now held the balance at Westminster. In 1886 Gladstone proposed further land reform - effectively, a government-sponsored, large-scale transfer of land ownership from the landed gentry to the farmers - and the establishment of a devolved parliament in Dublin. It was a bold, two-pronged attempt to stabilize the United Kingdom: land reform would create a class of contented, conservative smallholders, while Home Rule would satisfy the nationalists' demands and establish institutional mechanisms which in future would articulate Irish 'national interest', but do so within the wider British Empire. ${ }^{32}$ It was an integrationist strategy with an explicit pluralist agenda: the United Kingdom consisted of different nations, and their difference was to be affirmed as a means of re-establishing the United Kingdom's overall cohesion. It was reassuring that electoral 'democracy' was mediated through the intrinsically moderate, exclusively male householder electorate. Gladstone hoped that this partial coopting of democratic impulses and provincial interests would stabilize the system, in the same way that the adoption of the Durham Report had consolidated the Empire after 1840.

Under Lord Salisbury, the Conservative party adopted the opposite strategy, based on an assimilationist philosophy: they denounced Home Rule as the first step towards the disintegration of the Empire and argued that the way forward demanded not constitutional , but primarily social reform within a centralized United Kingdom - making Ireland more like England, in so far as it was possible. One big advantage of this strategy was that it was consistent with the jingoistic spirit of the age and enjoyed widespread support in 'middle 
England'. More importantly, Salisbury's stand helped to split the Liberal party in 1886, with the anti-Home Rule wing abandoning Gladstone and entering into what was to become a permanent 'Unionist' alliance with the Conservative party, one which proved a lasting success and was in office for most of the time from 1886 to $1905 .{ }^{33}$ Interestingly, the Liberal seceders' most dynamic leader, the social imperialist Joseph Chamberlain (1836-1914), was influenced by the French republican model of social imperialism, which at the time was the most assimilationist in Europe..$^{34}$ Driven by a Darwinian angst about the competition between great powers - Germany, France, Russia, the USA and Britain Chamberlain wanted to build a stronger and more united Empire applying to it a collectivist and interventionist philosophy. ${ }^{35}$

In Ireland, in response to national separatism, the Conservative and Liberal Unionist governments (1886-92 and1895-1905) tried to establish a higher synthesis of what the national interest might mean. For this purpose they started to address the Irish question as one requiring two answers: on the one hand, defeating national separatism and agrarian terrorism; on the other, modernizing the country. ${ }^{36}$ Their land policy was generous and radical, culminating, in 1903, with the Wyndham Land Act. This was the final instalment of the sort of land purchase that Gladstone would have wished to carry out through one comprehensive big law in 1886. Salisbury and his governments implemented the same policy gradually over nearly twenty years. Meanwhile, they adopted repressive legislation to control rural unrest. Such 'Constructive' Unionism commanded a solid majority at Westminster and became skilled in 'surfing' the imperialist wave, which by 1900 appeared unstoppable. By then, they also believed that they had solved the problem of how to 'manage' a democratic electorate by avoiding the inconveniences of democracy: this required addressing some of the causes of economic instability and popular anxiety, while unifying 'England' against 'the enemy within' Irish nationalists and Gladstonian Liberals - allegedly intent on destroying the Empire.

However, there were two problems with this strategy. The first was that, while Ireland was small and affordable, if 'Constructive' Unionist reforms were applied to the rest of the United Kingdom, they would become very expensive. ${ }^{37}$ For example, Chamberlain had long wished to introduce old-age pensions. The latter would require new sources of revenue, which would could come either from taxing more heavily the income of the wealthy (a strategy which was not popular with the Conservative party), or the consumption of the poor (which was unacceptable to their electors). The second problem was that whatever the government did for the Irish, it was never enough, because nationalists were not demanding better government from London, but self-government, whether good or bad.

The Liberals, who returned to power in 1906, had a different view. Gladstone was by then dead, but his party inherited and further developed his vision of the empire not as a unitary entity run by a London elite, but as a partnership of four nations, involving the emerging regional elites in the redefinition of both British and Irish interests through devolved legislative assemblies. ${ }^{38}$ Indeed, by 1912 Winston Churchill was working a project of 'Home Rule All Round', with devolved assemblies for both Scotland and Wales and the English 'regions' ${ }^{39}$ Furthermore, this was a dynamic strategy in the sense that it could be extended beyond the United Kingdom to coopt the colonial elites overseas. Indeed, in 1910 this strategy was successfully implemented in the then newly-established Union of South Africa, where it worked wonders by reconciling most of the defeated Boers to British rule, so much so, that one of their leaders, Jan Smuts, immediately 
became a leading figure in Liberal empire-building. However, the Liberals' renewed attempt to apply devolution to Ireland in 1912 resulted in a major constitutional crisis. ${ }^{40}$

Two things are remarkable in the constitutional crises of 1911-14: the first is that both the British and the Irish electorate had a keener interest in the Home Rule Question and the future of the Union, than in either radical social reform (including non-contributory old age pensions, introduced by the Liberals in 1908) ${ }^{41}$ or the ending of the House of Lords' veto on legislation passed by the elected House of Commons. The second is that Home Rule was stopped not by parliamentary means but by a 'popular' insurrection in Ulster: in September 1912, after a well-orchestrated campaign, about half-a-million Ulster men and women signed two parallel documents committing them to resist the establishment of a devolved parliament in Dublin by all means. They claimed 'that Home Rule would be disastrous to the material well-being of Ulster as well as of the whole of Ireland, subversive of our civil and religious freedom, destructive of our citizenship, and perilous to the unity of the Empire' (Solemn League and Covenant). Their threat was further upheld by the mobilization of a private army, the Ulster Volunteers, which in itself implied a claim to ultimate sovereignty, the right to use force, the ius ad bellum. ${ }^{42}$ Inevitably, the Nationalists responded by forming their own private army, the Irish Volunteers. In the spring of 1914 the island, indeed the United Kingdom as a whole, seemed on the brink of civil war when both Unionists and Nationalists started to import weapons from abroad, while the British army was in a state of quasi-mutiny. ${ }^{43}$

A few months later, the outbreak of the First World War changed everything. Britain and Ireland went into the war as ' $a$ Kingdom united', and furthermore remained so over the next few years. ${ }^{44}$ As it had already happened a hundred years earlier, during the Napoleonic Wars, for the duration of the 1914-18 war the United Kingdom held together well, despite the widely publicized 1916 Easter Rising. The German blockade and threat of an invasion created a solidarity that went beyond the question of the Union. ${ }^{45}$ The real turning point came only with the next general election in December 1918. For the first time, all adult males and some women above the age of thirty were entitled to vote. The election found Ireland more polarized than ever. In the south, a new nationalist party, Sinn Féin, won the overwhelming majority of the seats but refused to send MPs to Westminster and instead organized an independent republican parliament in Dublin, the first Dáil. The Unionists reaffirmed their control over the six northeast counties of Ulster. They were determined to retain Ulster's connection to the United Kingdom. In both Irelands electors voted not in favour of a programme, but against some 'enemy' - either Britain (in the nationalist south) or republican nationalism (in North-East Ulster), and this resulted in the squeezing out of the system of any parties which proposed compromise answers to the self-government questions, including the old National party and the moderate Unionists. Likewise, socialism, the politics of 'class struggle' and its Irish Labour party advocates were completely marginalized: in the South this outcome emerged despite, or because of, the support the party had offered to the national revolution.

Over the next two years such division was consolidated into territorial partition, In the South and the West, 26 Counties formed an economically conservative 'Free State', after a revolution (1919-23) which created a bourgeois/farmer state whose economic and social policies combined late-Victorian liberal laissez-faire with Catholic social teaching. ${ }^{46}$ In the six north-eastern counties of Ulster the British government created a new self-governing jurisdiction - Northern Ireland. Partition excluded from Northern Ireland three Ulster 
counties where the nationalist vote and the Catholic populations were stronger (Donegal, Moneghan and Cavan). This was an attempt to secure homogeneity and stability for the new Province which became one of the first examples of what sociologists call 'ethnic democracy'. ${ }^{47}$ Partition was formalized by the decisions of the 1925 Boundary commission, which effectively confirmed the border between the two Irish jurisdictions. ${ }^{48}$

Elsewhere in Britain the first quasi-universal suffrage election was far less decisive. The war had created a sense of national solidarity against both external enemies and new internal ones: with the Bolshevik Revolution threatening to spread to Central and even Western Europe, a majority of the British electors voted to stop what they regarded the most dangerous 'enemy within', identified not with the Irish separatists, but the British 'socialists'. This resulted in the traditional parties, the Conservatives and the Liberals, being confirmed as the dominant forces. However, the Liberal party was divided again, as in 1886, between the majority, which followed the Prime Minister, David Lloyd George, into a Coalition with the Conservatives; and a minority, which followed the former Prime Minister H. H. Asquith and remained faithful to pre-war Liberalism. The Labour party made some inroads, but remained largely marginal. ${ }^{49}$

\section{Conclusions}

Whatever happened to Scottish and Welsh aspirations to devolution? Between 1910 and the 1920s in Scotland there continued to be interest in the idea, until a series of economic crises and terminal industrial decay increased the country's dependence on London. This was paralleled by the decline of the Liberal party - the greatest champions of devolution - which lost support to Labour and the Unionist party (as the Conservatives called themselves north of the border). The Unionists were helped by the Protestant churches, deserting the Liberals when faced with the prospect of the rise of a 'socialist', 'Godless' (or, worse, Irish Catholic) Labour party. Thus Scotland united against its own variety of the 'enemy within'. Meanwhile Wales had been temporarily absorbed in 'unionist' politics, first by David Lloyd George - himself the greatest Welsh statesman ever ${ }^{50}$ - and then by the vigorous development of the Labour party. The latter owed more to Joseph Chamberlain than to Karl Marx and 'Constructive Unionism' became and remained their strategy until 1998.

Thus, from 1707 to 1885 a representative, but undemocratic, system of government, renewed the legitimacy of the ruling landed elite, while continuous economic growth strengthened popular deference towards them. Unity and a sense of common purpose depended on lack of democracy, which allowed for a drastic simplification of the 'interests' that mattered and needed to be considered in framing policy. These interests were primarily those of the landed elite and their local supporters. They were more or less effectively represented in parliament, which gave a voice to the wealthy without excluding regional differences thus managing 'Court versus Country' tensions while simultaneously encouraging the formation and renewal of a national United Kingdom elite.

From 1885, with the gradual advent of democracy, parliamentary centralization became contentious, and this resulted first in the break-up of the party system (1886), and then in near civil war (1914), and eventually the Partition of Ireland (1920). The system was brutally recalibrated by the impact of the First World War and the Irish Revolution. The latter eliminated the most troublesome of the 'Four Nations' and 'quarantined' whatever 
remained of the 'Irish Question' in British politics. ${ }^{51}$ In the 1930 s a new series of external emergencies and formidable enemies in the shape of Hitler, Mussolini and the Japanese ensured the further strengthening of a centralized of Union. Thus, if the 'world wars' of the eighteenth century made possible and necessary the Union between England and Scotland, the twentieth-century 'Thirty Years War' provided the system with a new lease of life..$^{52}$ However, none of the regional/national problems which had troubled the Union since 1885 had been solved by 1945 .

\section{BIBLIOGRAPHY}

\section{Primary sources}

Lord Bankton, An Institute of the Laws of Scotland (3 vols., Edinburgh 1751-3).

Bruce, John Report on the Events and Circumstances, which produced the Union of the Kingdoms of England and Scotland (2 vols., 1799).

Mitchel, John, The Last Conquest of Ireland (Perhaps), ed. by Patrick Maume (Dublin, UCD Press, 2005 - first edition Glasgow, 1861).

Stephen, James Fitzjames, Liberty, Equality, Fraternity (London, H. Elder \& Co., 1874).

\section{Secondary sources}

Barr, C. \& D. O Corráin, “Catholic Ireland”, in E. F. Biagini and M. E. Daly (eds.), The Cambridge Social History of Ireland (Cambridge, Cambridge University Press, 2017), pp. 68-87.

Bayly, Christopher A., The Birth of the Modern World (London, Wiley-Blackwell, 2004).

Beckett, Ian F., The Army and the Curragh Incident 1914 (London, Bodley Head for the Army Records Society, 1986).

Belich, James. Replenishing the earth: the settler revolution and the rise of the Angloworld (Oxford, Oxford University Press, 2009).

Bew, Paul, Land and the National Question in Ireland 1858-82 (Dublin, Gill \& Macmillan, 1979).

Bew, Paul, Enigma. A New Life of Charles Stewart Parnell (Dublin, Gill \& Macmillan, 2011).

Biagini, Eugenio F., "The Third Home Rule Bill in British History”, in G. Doherty (ed.), The Home Rule Crisis 1912-14 (Cork, Mercier Press, 2014), pp. 412-442.

Biagini, Eugenio F., British Democracy and Irish Nationalism, 1876-1906 (Cambridge, Cambridge University Press, 2002).

Blackstock, Allan, Loyalism in Ireland 1789-1829 (Woodbridge: Boydell Press, 2007).

Bowman, Timothy, Carson's Army. The Ulster Volunteer Force, 1910-1922 (Manchester, Manchester University Press, 2007). 
Browning, Reed, Political and Constitutional Ideas of the Court Whigs (Baton Rouge and London, Louisiana State University Press, 1982).

Cadiot, Juliette, Le laboratoire impérial: Russie-URSS 1870-1940 (Paris, CNRS editions, 2007).

Cadiot, Juliette, “L'année 1917 et l'Assemblée constituante en Russie. L'universalisme à l'épreuve de la diversité”, Vingtième Siècle. Revue d'histoire, 2017/3 ( ${ }^{\circ}$ 135), pp. 18-30.

Cain, P.J. \& A. G. Hopkins, British Imperialism. Innovation and Expansion 1688-1914 (London and New York, Longman, 1993).

Cawood, Ian, The Liberal Unionist party: a history (London, I. B. Tauris, 2012).

Colley, Linda, Acts of Union and Disunion. What has Held the UNITED KINGDOM together and what is dividing it? (London, Profile Books, 2014).

Comerford, R. V., The Fenians in context: Irish politics and society 1848-82 (Dublin, Wolfhound Press, 1985).

Curtin, Nancy J., The United Irishmen. Popular Politics in Ulster and Dublin, 1791-1798 (Oxford, Oxford University Press, 1998).

Daly, Mary E., Dublin. The Deposed Capital. A Social and Economic History 1860-1914 (Cork, Cork University Press, 2011).

Edgerton, David, Warfare State: Britain 1920-1970 (Cambridge, Cambridge University Press, 2005).

Ellis, John S., "Reconciling the Celt: British National Identity, Empire, and the 1911 Investiture of the Prince of Wales", Journal of British Studies, Vol. 37, No. 4 (Oct., 1998), pp. 391-418.

Evans, Richard J., The Pursuit of Power: Europe 1815-1914 (London, Viking, 2016).

Fry, M., "The Disruption of the Union”, in S. J. Brown and M. Fry (eds.), Scotland in the Age of the Disruption (Edinburgh, Edinburgh University Press, 1993), pp. 31-43.

Gailey, Andrew, Ireland and the Death of Kindness: The Experience of Constructive Unionism, 1890-1905 (Cork, Cork University Press, 1987).

Gallagher, Niamh, Ireland and the Great War: A Social and Political History (London, I. B. Tauris, 2019).

Godechot, François, France and the Atlantic Revolution of the Eighteenth Century, 1770-1799 (London, Collier-Macmillan, 1971).

Green, Ewen, The Crisis of Conservatism: the politics, economics and ideology of the Conservative Party, 1880-1914 (London, Routledge, 1994).

Green, Ewen, The Ideals of Empire: Economic and Political Thought, 1903-1913 (London, Routledge, 1998), six volumes.

Green, Ewen H. H., Ideologies of Conservatism. Conservative Political Ideas in the Twentieth Century (Oxford, Oxford University Press, 2002).

Griffin, Patrick, The People of No Name. Ireland's Ulster Scots, America's Scots Irish, and the creation of the British Atlantic World 1689-1764 (Princeton, Princeton University Press, 2001).

Hiden, John W. \& David J. Smith, “Looking beyond the Nation State: A Baltic Vision for National Minorities between the Wars", Journal of Contemporary History, Vol. 41, No. 3 (Jul. 2006), pp. 387-99.

Hoppit, J., A Land of Liberty?: England 1689-1727 (Oxford, Oxford University Presss, 2000).

Hudson, David R. C., The Ireland that We Made: Arthur and Gerald Balfour's contributions to the origins of modern Ireland (Akron OH, University of Akron Press, 2003). 
Hutchison, I. G. C., A Political History of Scotland 1832-1924: parties, elections and issues (Edinburgh, Donald, 1986).

Israel, Jonathan, The expanding blaze. How the American Revolution ignited the world, 1775-1848 (Princeton, Princeton University Press, 2018).

Jackson, Alvin, The Ulster party. Irish Unionism in the House of Commons, 1884-1911 (Oxford, Clarendon Press, 1989).

Jackson, Alvin, The Two Unions. Ireland, Scotland and the Survival of the United Kingdom, 1707-2007 (Oxford, Oxford University Press, 2012).

Jameson, John Franklin, The American Revolution Considered as a Social Movement (Princeton, 1926).

Jenkins, Brian, Irish Nationalism and the British State. From Repeal to Revolutionary Nationalism (Montreal \& London, McGill-Queen's University Press, 2006).

Kendle, John, Ireland and the federal solution: the debate over the United Kingdom constitution (Montral, McGill-Queen's University Press, 1989).

Kenyon, J. P., Revolution Principles: The Politics of Party, 1689-1720 (Cambridge, Cambridge University Press, 1977).

Kidd, Colin, Union and Unionisms. Political Thought in Scotland, 1500-2000 (Cambridge, Cambridge University Press, 2008).

Knirck, Jason, Afterimage of the Revolution: Cumann na nGaedheal and Irish Politics, 1922-1932 (Madison, WI, University of Wisconsin Press, 2014).

Lloyd-Jones, Naomi, "Liberalism, Scottish Nationalism and the Home Rule Crisis, c.1886- 93", English Historical Review (2014), pp. 862-87.

Lloyd-Jones, Naomi, “Liberal Unionism and political representation in Wales, c.1886-1893", Historical Research, 88:241 (August 2015), pp. 482-507.

MacColl, Allan W., Land, Faith and the Crofting Community. Christianity and Social Criticism in the Highlands of Scotland, 1843-1893 (Edinburgh, Edinburgh University Press, 2006).

McKibbin, Ross I., The Evolution of the Labour party 1910-1924 (Oxford, Oxford University Press, 1974).

Marsh, Peter T., Bargaining on Europe: Britain and the First Common Market, 1860-1892 (New Haven, Yale University Press, 1999).

Matthew, H. C. G., Gladstone 1875-1898 (Oxford, Oxford University Press, 1995).

Moloney, Senan, The Phoenix Park Murders: Conspiracy, Betrayal \& Retribution (Cork, Mercier Press, 2006).

Morgan, Kenneth O., Rebirth of a Nation. Wales 1880-1980 (Oxford, Oxford University Press, 1982).

Morgan, Kenneth O., Lloyd George Welsh radical as world statesman (Cardiff, 1963).

Morgan, Kenneth O., Consensus and Disunity. The Lloyd George Coalition Government 1918-1922 (Oxford, 1986).

Moody, Theodore W., "Michael Davitt and the British labour movement 1882-1906", Transactions of the Royal Historical Society, Vol. 3 (1953), pp. 53-76.

Moulton, Mo, Ireland and the Irish in inter-war England (Cambridge, Cambridge University Press, 2014). 
Murray, Paul, The Irish Boundary Commission and its Origins: 1885-1925 (Dublin, University College Dublin Press, 2011).

Newby, Andrew G., Ireland, Radicalism and the Scottish Highlands, c.1870-1912 (Edinburgh, Edinburgh University Press, 2007).

Palmer, R. R., The age of the democratic revolution [electronic resource]: a political history of Europe and America, 1760-1800 (Princeton, 1959-64, 2 vols.).

Peled, Yoav, The Challenge of Ethnic Democracy: The State and Minority Groups in Israel, Poland and Northern Ireland (London, Routledge, 2014).

Pennell, Catriona, A Kingdom United: Popular Responses to the Outbreak of the First World War in Britain and Ireland (Oxford, Oxford University Press, 2012).

Regan, John M., The Irish Counter-revolution 1921-1936: treatyite politics and settlement in independent Ireland (Dublin, 1999).

Moulton, Mo, Ireland and the Irish in inter-war England (Cambridge, 2014).

Murray, Paul, The Irish Boundary Commission and its Origins: 1885-1925 (Dublin, 2011).

Ó Catháin, Máirtín “Michael Davitt in Scotland”, Saothair, Vol. 25 (2000), pp. 19-26.

Ó Gráda, Cormac, Ireland. A New Economic History 1780-1939 (Oxford, Oxford University Press, 1994).

Ó Gráda, Cormac, “'The Greatest Blessing of All': The Old Age Pension in Ireland”, Past \& Present, 175, 1 (2002), pp. 124-61.

Ollerenshaw, Philip, "Business and Finance, 1780-1945”, in Liam Kennedy and Philip Ollerenshaw (eds), Ulster since 1600. Politics, Economy, Society (Oxford, Oxford University Press, 2013), pp. 177-194.

Osterhammel, Jurgen, The Transformation of the World. A Global History of the Nineteenth Century (Princeton, Princeton University Press, 2014).

Peled, Y., The Challenge of Ethnic Democracy: The State and Minority Groups in Israel, Poland and Northern Ireland (London, 2014).

Polaskly, Janet, Revolutions without borders. The call to liberty in the Atlantic world (New Haven and London, Yale University Press, 2015).

Pugh, Martin, "Working-Class Experience and State Social Welfare, 1908-1914: Old Age Pensions Reconsidered”, The Historical Journal, 45, No. 4 (2002), pp. 775-96.

Read, Charles, “The 'Repeal Year' in Ireland: An Economic Reassessment”, The Historical Journal, 58:1 (2015), pp. 111-135.

Regan, Jennifer M., The Irish Counter-revolution 1921-1936 (Dublin, 2001).

Rogers, Nicholas, Whigs and Cities: popular politics in the age of Walpole and Pitt (Oxford, Clarendon Press, 1989).

Shaw, John, "Land, People and nation: Historicist Voices in the Highland Land Campaign, c. 1850-1883", in Eugenio F. Biagini (ed.), Citizenship and Community, Liberals, Radicals and Collective Identities in the British Isles, 1865-1931 (Cambridge, Cambridge University Press, 1996), pp. 305-24 Tönnies, Ferdinand, Community and Civil Society (Cambridge, Cambridge University Press, 2001). Turner, Frederick Jackson, "The Significance of the Frontier in American History," Report of the American Historical Association (1893), pp. 199-227. 
Visana, Vikram, "Vernacular liberalism, capitalism and anti-imperialism in the political thought of Dafdabhai Naoroji”, The Historical Journal, 59(3) (2016), pp. 775-97.

Walker, Brian M., Ulster politics. The formative years, 1847-1888 (Belfast, Ulster Historical Foundation and Queen's University of Belfast, Institute of Irish Studies, 1989).

Weight, Richard, Patriots. National identity in Britain, 1940-2000 (London, Macmillan 2002).

Wilson, (Major) L. “The 'Country' versus the 'Court': a republican consensus and party debate in the Bank War", Journal of the Early Republic, vol.15, 4 (Winter 1995), pp. 642-3.

Wong, John Y., Deadly Dreams. Opium and the Arrow War (1856-1860) in China (Cambridge, Cambridge University Press, 1998).

\section{NOTES}

1. Vikram Visana, "Vernacular liberalism, capitalism and anti-imperialism in the political thought of Dafdabhai Naoroji”, The Historical Journal, 59(3) (2016), pp. 775-97.

2. See Juliette Cadiot, Le laboratoire impérial: Russie-URSS 1870-1940 (Paris, CNRS éditions, 2007); Id., "L'année 1917 et l'Assemblée constituante en Russie. L'universalisme à l'épreuve de la diversité", Vingtième Siècle. Revue d'histoire, 2017/3 ( ${ }^{\circ}$ 135), pp. 18-30; and John W. Hiden and David J. Smith. "Looking beyond the Nation State: A Baltic Vision for National Minorities between the Wars", Journal of Contemporary History, Vol. 41, No. 3 (July 2006), pp. 387-99.

3. Linda Colley, Acts of Union and Disunion. What has held the United Kingdom together and what is dividing it? (London, Profile Books, 2014), p. 144.

4. Reed Browning, Political and Constitutional Ideas of the Court Whigs (Baton Rouge and London, Louisiana State University Press, 1982), pp. 175-209; Nicholas Rogers, Whigs and Cities: popular politics in the age of Walpole and Pitt (Oxford, Clarendon Press, 1989), pp. 46-132; P. J. Cain and A. G. Hopkins, British Imperialism. Innovation and Expansion 1688-1914 (London and New York, Longman, 1993), pp. 58-71. For a parallel distinction in early US history see Major L. Wilson, "The 'Country' versus the 'Court': a republican consensus and party debate in the Bank War", Journal of the Early Republic, vol.15, 4 (Winter 1995), pp. 642-3.

5. J. P. Kenyon, Revolution Principles: The Politics of Party, 1689-1720 (Cambridge, Cambridge University Press, 1977); J. Hoppit, A Land of Liberty?: England 1689-1727 (Oxford, Oxford University Press, 2000).

6. J. Belich, Replenishing the earth: the settler revolution and the rise of the Angloworld (Oxford, Oxford University Press, 2009).

7. In political terms, the "settler revolution" became the British equivalent of the "American dream ", the United Kingdom counterpart of Turner's "Frontier" factor in American politics - a safety valve for the oppressed and disinherited (Frederick Jackson Turner, "The Significance of the Frontier in American History," Report of the American Historical Association (1893), pp. 199-227; John Franklin Jameson, The American Revolution Considered as a Social Movement (Princeton, 1926). It explains - to an extent - the weakness of social-revolutionary movements in nineteenth-century Britain and Ireland.

8. Jurgen Osterhammel, The Transformation of the World. A Global History of the Nineteenth Century (Princeton, Princeton University Press, 2014), p. 413.

9. Richard J. Evans, The Pursuit of Power: Europe 1815-1914 (London, Viking, 2016).

10. James Fitzjames Stephen, Liberty, Equality, Fraternity (London, H. Elder \& Co., 1874), p. 147.

11. John Y. Wong, Deadly Dreams. Opium and the Arrow War (1856-1860) in China (Cambridge, Cambridge University Press, 1998). 
12. Mary E. Daly, Dublin. The Deposed Capital. A Social and Economic History 1860-1914 (Cork, Cork University Press, 2011).

13. Charles Read, "The 'Repeal Year' in Ireland: An Economic Reassessment”, The Historical Journal , 58:1 (2015), pp. 111-135.

14. John Mitchel, The Last Conquest of Ireland (Perhaps), ed. by Patrick Maume (Dublin, UCD Press, 2005 - first edition Glasgow, 1861).

15. Cormac Ó Gráda, Ireland. A New Economic History 1780-1939 (Oxford, Oxford University Press, 1994), pp. 273-313; Philip Ollerenshaw, 'Business and Finance, 1780-1945', in Liam Kennedy and Philip Ollerenshaw (eds.), Ulster since 1600. Politics, Economy, Society (Oxford, Oxford University Press, 2013), pp. 177-194.

16. Colin Kidd, Union and Unionisms. Political Thought in Scotland, 1500-2000 (Cambridge, Cambridge University Press, 2008), 102, summarizing and quoting Lord Bankton, An Institute of the Laws of Scotland (3 vols., Edinburgh 1751-3), I, 22; and John Bruce, Report on the Events and Circumstances, which produced the Union of the Kingdoms of England and Scotland (2 vols., 1799), I, p.401.

17. Rev. W. Wood, speaking at Langholm (Dumfries and Galloway) in January 1843, quoted in M. Fry, "The Disruption of the Union", in S. J. Brown and M. Fry (eds.), Scotland in the Age of the Disruption (Edinburgh, Edinburgh University Press, 1993), p. 42.

18. Ibid., p. 31.

19. Allan W. MacColl, Land, Faith and the Crofting Community. Christianity and Social Criticism in the Highlands of Scotland, 1843-1893 (Edinburgh, Edinburgh University Press, 2006); Naomi Lloyd-Jones, "Liberalism, Scottish Nationalism and the Home Rule Crisis, c.1886-93", English Historical Review (2014), pp. 862-87.

20. By contrast, London had become the protector of the Catholic religion, and, under the aegis of George III, in 1795 the Dublin Protestant parliament had established a seminary at Maynooth for the training of the Irish Catholic clergy: C. Barr \& D. O Corráin, "Catholic Ireland", in E. F. Biagini and M. E. Daly (eds.), The Cambridge Social History of Ireland (Cambridge, Cambridge University Press, 2017), pp. 68-70.

21. Alvin Jackson, The Two Unions. Ireland, Scotland and the Survival of the United Kingdom, 1707-2007 (Oxford, Oxford University Press, 2012), pp. 88-114.

22. Ferdinand Tönnies, Community and Civil Society (Cambridge, Cambridge University Press, 2001).

23. Nancy J. Curtin, The United Irishmen. Popular Politics in Ulster and Dublin, 1791-1798 (Oxford, Oxford University Press, 1998).

24. Allan Blackstock, Loyalism in Ireland 1789-1829 (Woodbridge: Boydell Press, 2007), pp. 70-96.

25. R. R. Palmer, The age of the democratic revolution [electronic resource]: a political history of Europe and America, 1760-1800 (Princeton, 1959-64, 2 vols.); François Godechot, France and the Atlantic Revolution of the Eighteenth Century, 1770-1799 (London, Collier-Macmillan, 1971); Christopher A. Bayly, The Birth of the Modern World (London, Wiley-Blackwell, 2004); Patrick Griffin, The People of No Name. Ireland's Ulster Scots, America's Scots Irish, and the creation of the British Atlantic World 1689-1764 (Princeton, Princeton University Press, 2001); and Janet Polaskly, Revolutions without borders. The call to liberty in the Atlantic world (New Haven and London, Yale University Press, 2015). The most recent and authoritative statement of this interpretation is Jonathan Israel, The expanding blaze. How the American Revolution ignited the world, 1775-1848 (Princeton, Princeton University Press, 2018).

26. In 1848 a small-scale rebellion was a complete fiasco and later the Fenian movement, started in 1858, was much more militant in America than in Ireland: R. V. Comerford, The Fenians in context: Irish politics and society 1848-82 (Dublin, Wolfhound Press, 1985); Brian Jenkins, Irish Nationalism and the British State. From Repeal to Revolutionary Nationalism (Montreal \& London, McGill-Queen's University Press, 2006). 
27. Paul Bew, Land and the National Question in Ireland 1858-82 (Dublin, Gill \& Macmillan, 1979); idem, Enigma. A New Life of Charles Stewart Parnell (Dublin, Gill \& Macmillan, 2011).

28. Cavendish was related to Gladstone's through the latter's wife. He was murdered together with the Permanent Undersecretary, T. H. Burke: see Senan Moloney, The Phoenix Park Murders: Conspiracy, Betrayal \& Retribution (Cork, Mercier Press, 2006).

29. In both 1885 and 1886 the National party secured a majority of the seats in the nine counties of Ulster, in some cases by building alliances with Liberal Protestants: Brian M. Walker, Ulster politics. The formative years, 1847-1888 (Belfast, Ulster Historical Foundation and Queen's University of Belfast, Institute of Irish Studies, 1989); Alvin Jackson, The Ulster party. Irish Unionism in the House of Commons, 1884-1911 (Oxford, Clarendon Press, 1989).

30. Kenneth O. Morgan, Rebirth of a Nation. Wales 1880-1980 (Oxford, Oxford University Press, 1982); Naomi Lloyd-Jones, "Liberal Unionism and political representation in Wales, c.1886-1893", Historical Research, 88:241 (August 2015), pp. 482-507. On land reform see Theodore W. Moody, "Michael Davitt and the British labour movement 1882-1906", Transactions of the Royal Historical Society, Vol. 3 (1953), pp. 53-76.

31. John Shaw, "Land, People and nation: Historicist Voices in the Highland Land Campaign, c. 1850-1883", in Eugenio F. Biagini (ed.), Citizenship and Community, Liberals, Radicals and Collective Identities in the British Isles, 1865-1931 (Cambridge, Cambridge University Press, 1996), pp. 305-24; Máirtín Ó Catháin, "Michael Davitt in Scotland", Saothair, Vol. 25 (2000), pp. 19-26; Andrew G. Newby, Ireland, Radicalism and the Scottish Highlands, c.1870-1912 (Edinburgh, Edinburgh University Press, 2007).

32. H. C. G. Matthew, Gladstone 1875-1898, vol. 2 (Oxford, Oxford University Press, 1995), pp. 239-58. 33. Peter T. Marsh, Bargaining on Europe: Britain and the First Common Market, 1860-1892 (New Haven, Yale University Press, 1999); Ian Cawood, The Liberal Unionist party: a history (London, I. B. Tauris, 2012).

34. Eugenio F. Biagini, British Democracy and Irish Nationalism, 1876-1906 (Cambridge, Cambridge University Press, 2002), p. 218.

35. Ewen H. H. Green, Ideologies of Conservatism. Conservative Political Ideas in the Twentieth Century (Oxford, Oxford University Press, 2002), pp. 42-71; see also his edited The Ideals of Empire: Economic and Political Thought, 1903-1913 (London, Routledge, 1998), six volumes.

36. Andrew Gailey, Ireland and the Death of Kindness: The Experience of Constructive Unionism, 1890-1905 (Cork, Cork University Press, 1987); David R. C. Hudson, The Ireland that We Made: Arthur and Gerald Balfour's contributions to the origins of modern Ireland (Akron $\mathrm{OH}$, University of Akron Press, 2003).

37. Ewen H. H. Green, The Crisis of Conservatism: the politics, economics and ideology of the Conservative Party, 1880-1914 (London, Routledge, 1994).

38. John S. Ellis, "Reconciling the Celt: British National Identity, Empire, and the 1911 Investiture of the Prince of Wales", Journal of British Studies, Vol. 37, No. 4 (Oct., 1998), pp. 391-418.

39. John Kendle, Ireland and the Federal Solution: the debate over the United Kingdom constitution (Montreal, McGill-Queen's University Press, 1989).

40. Eugenio F. Biagini, "The Third Home Rule Bill in British History”, in G. Doherty (ed.), The Home Rule Crisis 1912-14 (Cork, Mercier Press, 2014), pp. 412-442.

41. Cormac Ó Gráda, “'The Greatest Blessing of All': The Old Age Pension in Ireland”, Past \& Present, 175, 1 (2002), pp. 124-61; Martin Pugh, "Working-Class Experience and State Social Welfare, 1908-1914: Old Age Pensions Reconsidered”, The Historical Journal, 45, No. 4 (2002), pp. 775-96.

42. Timothy Bowman, Carson's Army. The Ulster Volunteer Force, 1910-1922 (Manchester, Manchester University Press, 2007).

43. Ian F. Beckett, The Army and the Curragh Incident 1914 (London, Bodley Head for the Army Records Society, 1986). 
44. Catriona Pennell, A Kingdom United: Popular Responses to the Outbreak of the First World War in Britain and Ireland (Oxford, Oxford University Press, 2012).

45. Niamh Gallagher, Ireland and the Great War: A Social and Political History (London, I. B. Tauris, 2019).

46. John M. Regan, The Irish Counter-revolution 1921-1936: 1921-1936: treatyite politics and settlement in independent Ireland (Dublin, 1999).

47. Y. Peled, The Challenge of Ethnic Democracy: The State and Minority Groups in Israel, Poland and Northern Ireland (London, Routledge, 2014).

48. Paul Murray, The Irish Boundary Commission and its Origins: 1885-1925 (Dublin, University College Dublin Press, 2011); Jason Knirck, Afterimage of the Revolution: Cumann na nGaedheal and Irish Politics, 1922-1932 (Madison, WI, University of Wisconsin Press, 2014).

49. Kenneth O. Morgan, Consensus and Disunity. The Lloyd George Coalition Government 1918-1922 (Oxford, 1986), pp. 46-94; Ross I. McKibbin, The Evolution of the Labour party 1910-1924 (Oxford, Oxford University Press, 1974), pp. 88-111; I.G.C.Hutchison, A Political History of Scotland 1832-1924: parties, elections and issues (Edinburgh, Donald, 1986), pp. 309-28.

50. Kenneth O. Morgan, Lloyd George Welsh radical as world statesman (Cardiff, 1963).

51. Mo Moulton, Ireland and the Irish in inter-war England (Cambridge, Cambridge University Press, 2014).

52. David Edgerton, Warfare State: Britain 1920-1970 (Cambridge, Cambridge University Press, 2005); Richard Weight, Patriots. National identity in Britain, 1940-2000 (London, Macmillan, 2002).

\section{ABSTRACTS}

From 1885 to 1921 United Kingdom politics were polarized around the question of parliamentary devolution for Ireland (Home Rule). A major argument against Home Rule was that it would have been incompatible with the survival of the British Empire and indeed of the United Kingdom, because sovereignty could not be divided. However, Home Rule supporters insisted that the proposal was in the Irish national interest. This claim was in itself divisive in Ireland, as well as within the United Kingdom as a whole, and set the South against Ulster, which by 1912 was (literally) up in arms against any idea of weakening or diluting the Union with Britain. By 1887 Liberals in both Scotland and (soon afterwards) in Wales started to campaign for their own form of Home Rule. Ostensibly only an 'Irish' question, Home Rule was in fact the beginning of a wider debate about the governance of the United Kingdom and the tension between a centralized political system and the claims of ethnic groups and distinct regions in a multi-national state. This article examines the wider significance of the crisis in the constitutional rebalancing of a liberal, but still undemocratic, state. It will start from the time when the British system was at its apex, between 1707 and 1885. In this period parliament provided social and cultural legitimacy for the centralization of power and created cohesion for the wider imperial project. Second, this article focuses on the advent of democracy from 1885, and the way the latter made it more difficult for parliament to agree on the 'national' interest - especially when the latter depended on finding common ground between four nations.

De 1885 à 1921, la vie politique britannique fut dominée par la question de la dévolution parlementaire pour l'Irlande (Home Rule). Un des arguments contre le Home Rule fut qu'une telle mesure serait incompatible avec la survie de l'Empire britannique et aussi celle du Royaume-Uni 
parce que la souveraineté britannique ne pouvait être divisée. Cependant, les partisans du Home Rule soutenaient que la proposition était dans l'intérêt national de l'Irlande. Cette revendication divisait l'Irlande ainsi que le Royaume-Uni dans son ensemble et opposa le sud de l'Irlande à l'Ulster qui, en 1912, avait littéralement pris les armes contre l'idée d'affaiblir ou de diluer l'Union avec la Grande-Bretagne. En 1887, les libéraux en Écosse puis au Pays de Galles s'étaient lancés dans une campagne visant à obtenir leur propre forme d'autonomie législative. Si la question du Home Rule fut à l'origine ostensiblement un problème irlandais, elle devint le sujet d'un plus vaste débat concernant non seulement la gouvernance du Royaume-Uni mais aussi les tensions provoquées par l'existence d'un système politique centralisé d'une part et, d'autre part, l'expression de revendications de la part de groupes ethniques vivant dans des régions distinctes au sein d'un état multinational. Cet article examine le sens plus large pris par la question du Home Rule pendant une période de rééquilibrage constitutionnel dans un état certes libéral mais encore non-démocratique. L'étude démarre au moment où le système politique britannique était à son apogée, entre 1707 et 1885 . A cette époque le parlement donnait une légitimité sociale et culturelle à la centralisation du pouvoir et apportait une cohésion au plus vaste projet impérial. L'article se concentre ensuite sur l'avènement de la démocratie à partir de 1885 et sur la façon dont celui-ci compliqua la tâche du parlement lorsqu'il s'agissait de s'entendre sur l'intérêt «national », en particulier lorsque ceci impliquait de trouver un terrain d'entente commun à quatre nations.

\section{INDEX}

Keywords: democracy, sovereignty, central / multi-national state, Empire, governance Mots-clés: démocratie, souveraineté, État central / multi-national, Empire, gouvernance

\section{AUTHOR}

\section{EUGENIO BIAGINI}

Eugenio Federico Biagini is an ancien élève of the University and the Scuola Normale Superiore di Pisa. He has taught at Newcastle-upon-Tyne and Princeton universities, and has been a Visiting Fellow at Trinity College Dublin, Pisa, Bologna and the Princeton Institute for Advanced Studies (Willis F. Doney Member). He is Professor of Modern and Contemporary History at Cambridge, where he is also a Fellow of Sidney Sussex College. He is founder and one of the conveners of the Modern Irish History Seminar. He co-edited with Mary E. Daly The Cambridge Social History of Ireland (2017).

Eugenio Federico Biagini est ancien élève de la Scuola Normale Superiore de Pise. Il a enseigné à Newcastle-upon-Tyne et à Princeton. Après avoir été Professeur invité à Trinity College Dublin, Pise, Bologne, et à l'Institute for Advanced Studies de Princeton, il est actuellement Professeur d'histoire moderne et contemporaine à Cambridge, où il est également membre du Sidney Sussex College. Il a créé et co-anime le Modern Irish History Seminar. Avec Mary Daly, il a co-dirigé The Cambridge Social History of Ireland (2017). 